\title{
Preservation of Manuscripts in the Satras of Majuli: An Analytical Examination
}

\author{
Nijumoni Changmai
}

\begin{abstract}
The word manuscript is derived from the Latin word manu, meaning by hand and scriber meaning to write. Thus any book or documents written by hand is called manuscripts. Manuscripts are original source of human history available on various kinds of media like stone, clay, palm leaves, bark, animal skin, cloth paper etc. Majuli is a largest island of India where have lots of Satras. The Satras preserve lots of manuscripts. Manuscripts are life-blood of history. The study of manuscripts is reveals the social, cultural, historical, artistic and aesthetic changes that have occurred in the course of development of civilization. Thus collecting and preserving of manuscripts is preserving the intellectual heritage.
\end{abstract}

Keywords: Preservation, Manuscripts, collection, Satras, Climate, History.

\section{INTRODUCTION}

Preservation is the process of keeping an object safe from harm or loss, damage, destruction or decay and maintains it in a reasonably sound condition for present and future use. There are various numbers of Satras in Majuli where have lots of manuscripts. Majuli, a sub-division of the Jorhat district, but very recently it is introdeuced as district in Assam and situated between 260-250 and 270-120 North latitude and 930-390 and 940-350 East longitude, is well known as one of the largest river island in the world that immensely deserve the glory of a global heritage site for its unique scenic beauty and the cultural creativity of the indigenous communities that the island has nurtured since antiquity. Where fogs, thunderstorms and dust rising are the characteristic features of weather. Besides, in these region hazards of manuscripts particularly the environmental factor has been affected by temperature, humidity, water and such other damaging agents. At present 40 (forty) numbers of Satras are present in Majuli. Although, four well known Satras, namely Auniati Satra, Garmur Satra, Uttor Komolabari Satra, and Chamuguri Satra are situated in Majuli and the social and cultural process in the island are by and large oriented towards these Satras. On the other hand the immigration and settlements of the other communities over the centuries have significantly affected the demographic complexion in almost all parts of the valley; the Majuli Island is almost an island of the traditional Assamese life and culture.

\section{OBJECTIVES}

- To trace out the need of Manuscripts preservation.

- To study about the various factor and causes that may damage and destroy manuscripts.

- To create a public awareness for preservation of valuable manuscripts.

\section{List OF Manuscripts Preserved in SurVeyed SATRAS OF MAJULI :}

\section{1. Uttar Kamalabari Satra:}

- Mahabharatar Yuddha

- Mahabhagavata

- Rukmini Haran

- Janma Rahashya

- Bargeet

- Kirton Ghosa

- Padma Puran

- Nam Malika

- Ratnawali

- Bhakti Pradip

- Bali Chalan

- Syamanta Haran

- Bhuyan Bonsar Utpatti charitra puthi

- Karuna Badh

- Siva Parvati etc.

\subsection{Auniati Satra :}

- Kumar sambhav

- Mahapuja Bidhi

- Dasam

- Sundara Kanda Ramayan

- Kirton Ghosa

- Hari Chandra Akhyan

- Anadi patan

- Bhakti Ratnawali

- Babrubahonor Yuddha

- Satrunjay

\subsection{Chamuguri Satra:}

- Sri Charit

- Namghosa

- Nam Malika

- Bhaktti Ratnakar

- Janma Rahashya

- Hamdoi Montra

- Sarbaroga mantra Nidan

- Adikanda Ramayana

- Rukmini Haran Kabya 


\subsection{Garmur Satra :}

- Bhagavata ix canto

- Dasam 6 copies

- Ramayana 3 copies

- Gita

- Lila Mala

- Kalia Daman Nat

- Krishna Lila Nat

- Ayurveda Nat

- Puja Bidhi

- Kriya Bidhi

- Sruti

The above mentioned Satras preserve many more manuscripts than those listed here with. Atleast, when I visited the satras in the year 2014, I could count as many as 80 useable manuscripts on various subjects. These useable manuscripts are classified into two categories in terms of dates; some are very old, as old as 300-400 years, while some others are quite new. This shows that the art and culture of manuscripts writing in these Satras continued since the beginning and till 20th century. Though, there is a huge number of old Manuscripts in the Satras of Majuli, a considerable amount of manuscripts have been destroyed in various reasons. Most of them have been destroyed by fire, water and insects. Other important causes of destruction of Assamese and Sanskrit manuscripts are natural calamities, humidity, chemical causes and the ignorance of proper preservation of manuscripts.

\section{TyPES OF MATERIAL USED FOR WRITING MANUSCRIPTS:}

Various kind of materials used for wrote the manuscripts. These were-Clay, Papyrus, Palm leave, Bark, Wood, Bone, Stone, Paper, Sanchipat, Tulapat, Leather etc.

\section{ACCESSIONing OF MANuSCRIPTS:}

One can perform the act of reasoning, unless one possesses power of accessioning. Accessioning helps to convert unorganized thought and impression into recognizable patterns. So accessioning of manuscripts is more important for the Satra's authority, library, or any other institution.

- Accession number

- Date of receipt of manuscripts

- Title of manuscripts

- Author

- Date of writing of Manuscripts

- Language

- Particulars of the source

- Material of Manuscripts

- Size of folios

- Serial No of folios

- Condition of Manuscripts

- Complete or uncompleted manuscripts

- Price

- Particulars of the bill

- Remarks etc.
On the other hand, some manuscripts are collected and others are donated by someone to the Satras. Importantly most of the Satra's authority is not recorded properly from where these manuscripts are collected and the name and address of the person who donated it to the Satras. There are so many other manuscripts are scattered in the area. If there will be a survey regarding it, a large number of manuscripts will be found. Because, still there have some manuscripts keeping by some Assamese family. They are preserving it by themselves and do not want to donate it because they think that if they donate it somewhere, it may misuse or may not preserved properly. In this case, classification and cataloguing is also important for proper save.

\subsection{Classification:}

The Satras authority has to find out a method or scheme of classification which suits the nature of its collection and clientele. Before the logical schemes of classification were originated books in libraries were arranged either by their accession number or alphabetical or by their author or title of manuscripts, language, publisher etc.

\subsection{Cataloguing:}

It is important to organizing human knowledge in Satras. It is an art of making records in such a manner that they may be readily identified, located and examined. Classification defines the place of a document on shelves. The catalogue is a guide map of documents of a library/Satra and any other type of institution.

\section{NeEds of Preservation of ManusCripts:}

The main function of Satras is to collect and preservation of knowledge for its dissemination to all. Its conservation for posterity is also an important duty of a public library. Because books or documents are the life blood of a great thinkers of the past and present. They represent the lifelong labours and research undertaken by the scholar. Before the invention of paper and printing press, scholars were begun to write on different writing materials. The process of manuscripts writing was laborious and costly.

The developed countries like England, America, Germany and French have tried their level best to preserve the old manuscripts and documents not only for their country but for other countries too. These are a type of evident from the printed catalogue of the library of world that we are the biggest producer of manuscripts on aspects of human knowledge. We could not save our most of the cultural heritage due to our backwardness. On the other hand the foreign rulers, travelers and writers have taken away the most valuable manuscripts and documents and translated them into their own language and we are still unaware about these manuscripts. Due to political and religious upheavals a large portion of manuscripts has been destroyed.

In present time, governments as well as NGO, has set up the manuscripts repositories on a large scale. These repositories have the distinction of preserving such old books and manuscripts which help in linking the ancient history of India in one complete chain. In 
most our repositories, it is seen that manuscripts are kept in close shelves and are not issued to the research students and ancient writers of the subject only because either they are in a very brittle condition or they are very rare. We should get them repaired, microfilmed and make available to the readers and research student. We have lots of manuscripts and documents in our religious places like Temple, Mathas, Satras etc. It is very sad to say that some manuscripts are destroyed by insects and time. In ancient time our ancestors were totally unaware about the manuscripts with which they could save their historical documents and valuable manuscripts. There are some enemies of manuscripts and other documents for which preservative measures should be taken.

\section{Factors Influencing the Preservation:}

A. Insects :

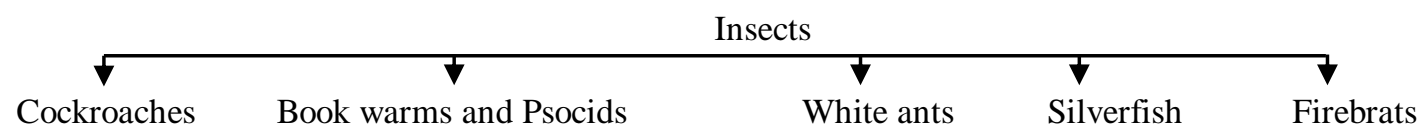

B. Rodents:

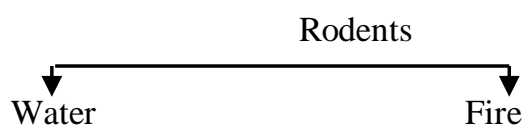

\subsection{Influence of the Climate Conditions: Temperature and Humidity}

Manuscript materials are affected by high temperature, too high and too low humidity, dust and acidic gases in the atmosphere and sunlight. These materials kept in a hot and dry climate become brittle. In the presence of excessive humidity paper often tends to crumble and become damp. Extreme variation of temperature in many places in Assam also affected flexibility of these materials.

More temperature and humidity may cause the growth and propagation Of pests as well as a variety of fungus commonly known as mildew.

\subsection{Atmospheric Pollution: Acidic gases and dust :}

The presence of acidic gases in the atmosphere, especially sulphur-dioxide and sulphurated hydrogen in the polluted air on paper and other writing is also accelerated by exposure to sunlight certain colours of paper, fabrics etc. fade and become fragile under the action of direct sunlight.

\section{Precaution against These InSects:}

Insecticidal powder like DDT or spray insecticides like pip or flit all place frequently at the dark corner wall's beneath and at the back of the rack and almirah.

Naphthalene is a good deterrent to insects and should be kept among manuscripts or other reading materials on shelves.

Rats and mice are most common pests among the rodents. For preventing rats and mice from entering the room all joints between the partition walls and main structure should be effectively sealed.

Dampness, stagnant air, sunlight and hot and dry climate bring about the deterioration of manuscripts. Deleterious influencing agents can be minimized by avoiding rooms which are damp, improperly ventilated and dark. A dry, well ventilated suitable room is needed for proper keeping of manuscripts.

Exposure of manuscripts to direct sunlight regularly will make manuscripts yellow and brittle. Exposure of manuscripts even if damp to direct sunlight should be avoided. Similarly manuscripts should be exposed to direct heat.
Accumulation of dust among manuscript is unhygienic and favours the growth of mildew. Using of electrically operated vacuum cleaner is an ideal method for it.

Manuscripts should be handled with care. If care is not observed in handling the manuscripts; all endeavours for proper preservation and storage will be vain while removing the manuscripts from shelves or almirah, these should not be dragged out from their places. Instead, these should be lightly lifted with both hands and also care being taken that other manuscripts will not disturbed.

\section{REPAIR OF MANUSCRIPTS:}

The most recent method of preservation of manuscripts and documents is by lamination through machine. This is a costly process and the National Archive of India uses this process. Hand lamination is also possible by an expert mender and binder. Before laminating a manuscript the quality of ink which is use in writing the manuscripts should be considered. In this connection it is suggested that if the ink of manuscript is faded, microfilm or Photostat copy should be taken.

Besides all these method there are other means of protection of manuscripts by hand repairing, chiffon and tissue the paper etc. In all these methods the binder should see the ink used in manuscripts. In case the permanent ink is used the mender will simply loose the sheet of a manuscripts and wet them in ordinary water and will apply chemically prepared adhesive past over the leaves of manuscripts and keep a piece of chiffon at one side and same process will adopted to the other side of the leaves. In case ordinary ink used in manuscripts mender will use foil and acetone as adhesive. In this process good quality of tissue paper should be used. In repairing manuscripts on palm leaf and brick bark. In case the palm leaf or brick bark is not available rag paper can be used. 


\section{Conclusion}

At last, it is prudent to any that, it is our duty to collect and to preserve the manuscripts from their inevitable destruction. The loss and destruction of manuscripts is a great loss for the nation as well as present civilization. The wisdom and knowledge in the page of manuscripts are being gradually forgotten, with the result that the confidence in our capacity and potentiality which have been kindled in us by the knowledge of our past achievements, lacks the requisite foundation to rest serve them from their inevitable destruction. These culturally rich manuscripts we must preserve for our future generation. Old manuscripts have social, educational, cultural and historical value. It reflects the ancient civilization of human beings. These valuable manuscripts should be preserved not only for present generation but for our future generation also. Collection and preservation of manuscripts should not be the main aim of Satra; these must be used. Otherwise, their hidden message will remain at the folio of the manuscripts itself.

\section{REFERENCES}

1. Baruah, Birinci Kumar: History of Assamese Literature; New Delhi Sahitya Academy, 1978, p 14-15, 17-80.

2. Borua Hem: Assamese Literature; New Delhi, National Book Trust. 1965, p 42-48, 49-50, 77-85.

3. Goswami, H.C: A Descriptive Catalogue of Assamese Manuscripts.

4. Marcel Dekker : Encyclopedia of Library and Information Science; New York.

5. Preservation and Conservation of Library Material. MLIE-101.

6. Sarmah, T: Auniati Satra Buronji.

7. Assamese Daily News Paper “Janasadharan”, 17th Aug/2007 